\title{
Growth Modulatory Role of Zinc in Prostate Cancer and Application to Cancer Therapeutics
}

\author{
Phuong Kim To ${ }^{1,2}$, Manh Hung Do ${ }^{1}$, Jin-Hyoung Cho ${ }^{3}$ and Chaeyong Jung ${ }^{1, *}$ \\ 1 Department of Anatomy, Chonnam National University Medical School, Gwangju 61469, Korea; \\ tkphuong2609@gmail.com (P.K.T.); manhhung.cnsh@gmail.com (M.H.D.) \\ 2 School of Medicine and Pharmacy, Tra Vinh University, Tra Vinh City 87000, Vietnam \\ 3 Department of Orthodontics, School of Dentistry, Chonnam National University, Gwangju 61186, Korea; \\ jhcho@jnu.ac.kr \\ * Correspondence: chjung@jnu.ac.kr; Tel.: +82-61-379-2705; Fax: +82-61-375-5834
}

Received: 19 February 2020; Accepted: 18 April 2020; Published: 23 April 2020

\begin{abstract}
Zinc is a group IIB heavy metal. It is an important regulator of major cell signaling pathways in most mammalian cells, functions as an antioxidant and plays a role in maintaining genomic stability. Zinc deficiency leads to severe diseases in the brain, pancreas, liver, kidneys and reproductive organs. Zinc loss occurs during tumor development in a variety of cancers. The prostate normally contains abundant intracellular zinc and zinc loss is a hallmark of the development of prostate cancer development. The underlying mechanism of this loss is not clearly understood. The knowledge that excess zinc prevents the growth of prostate cancers suggests that zinc-mediated therapeutics could be an effective approach for cancer prevention and treatment, although challenges remain. This review summarizes the specific roles of zinc in several cancer types focusing on prostate cancer. The relationship between prostate cancer and the dysregulation of zinc homeostasis is examined in detail in an effort to understand the role of zinc in prostate cancer.
\end{abstract}

Keywords: zinc; prostate; prostate cancer; tumor growth; homeostasis

\section{Introduction}

Studies of zinc in plants have a long history and have been followed by animal and human studies [1]. Zinc is an essential cellular component that functions as an antioxidant and maintains genomic stability [2]. This biologically important metal ion is a constituent of more than 3000 proteins and is a cofactor for over 300 enzymes [3,4]. Zinc is required for normal growth. Its deficiency leads to abnormal growth that include improper brain development, prolonged wound healing and an impaired immune system $[5,6]$. Inadequate zinc uptake increases the risk of infections and is linked to aging-related symptoms, such as decreased immune competence, delayed wound healing and alteration of certain neurological and psychological functions [1].

Zinc is an essential mediator of cell proliferation and differentiation through the regulation of DNA synthesis and mitosis. Zinc also affects DNA repair pathways by regulating multiple intracellular signaling pathways and altering proteins involved in DNA maintenance. The effects of zinc on DNA polymerase were studied in both zinc-sufficient and zinc-deficient conditions over 40 years ago $[7,8]$. DNA polymerase activity was markedly lower in zinc insufficient rat embryos compared with that in rat embryos that developed in a zinc-sufficient condition. Another study demonstrated that DNA damage was caused by diminution of zinc in peripheral blood cells and that repletion of zinc protected from zinc-mediated DNA damage [9]. Low intracellular concentration of zinc has been associated with the increased expression of apyrimidinic endonuclease, which cleaves DNA at sites of damage [10]. Zinc in the form of $\mathrm{ZnSO}_{4}$ inhibits the repair of damaged DNA damage induced by hydrogen peroxide $\left(\mathrm{H}_{2} \mathrm{O}_{2}\right)$ 
in K562 leukemia cells [11]. Withdrawal of zinc from PrEC prostate epithelial cells also stimulates breakage of single-strand DNA [12]. In addition, genes related to DNA damage response, including tumor protein p73 and MRE11, were downregulated in these cells, whereas the expression of p53 was increased. In murine fibroblasts, the addition of zinc can stimulate DNA synthesis and mitogenic signaling, whereas withdrawal of zinc reduces the secretion of growth hormone [13,14]. In Swiss 3T3 fibroblasts, $\mathrm{ZnSO}_{4}$ can reverse the inhibitory effect of diethylenetrinitrilopentaacetate (DTPA) on thymidine incorporation into DNA, suggesting that zinc stimulates cell growth by regulating cell cycle at the G1/S phase [15]. Intracellular zinc can block the G2/M transition in human bronchial epithelial cells by upregulating p53 and p21 activity [16]. These collective findings highlight the central role of zinc in the modulation of cell proliferation, mainly by affecting DNA synthesis. Therefore, zinc homeostasis plays a key role in the development of many diseases, in which the alteration of zinc is a common event.

\section{Zinc Biology}

The human body mass contains more than $2 \mathrm{~g}$ of zinc. Over $90 \%$ is distributed to most tissues, with only approximately $0.1 \%$ of this metal ion circulating in plasma $[17,18]$. Yet, this small amount of zinc plays an important role in maintaining homeostasis in the body. Zinc is stored in most organs and tissues with approximately $60 \%$ in skeletal muscle, $30 \%$ in bone and $5 \%$ in liver and skin and the remainder distributed in other tissues that include the brain, kidneys, pancreas and heart [19] (Figure 1). Excess zinc is primarily released through gastrointestinal secretion and endogenous excretion, with minor loss through urinary excretion. Although zinc is an essential trace element used by many enzymes and transcription factors, high concentrations are toxic to the cells. Cells adapt to overcome the toxicity by maintaining the balance of zinc uptake, intracellular storage and efflux [20]. In mammalian cells, intracellular zinc exists in two forms-a tightly or loosely bound form and an unbound form at very low concentrations as free $\mathrm{Zn}^{2+}$ ion [21]. Zinc binds avidly to metalloenzymes, metalloproteins and nucleoproteins and loosely to various proteins and amino acid ligands [22]. Many cells possess pico-molar levels of free zinc that is not bound to protein, which functions in cell control and cell-to-cell communication [23,24]. Therefore, strict regulation of the intracellular level of zinc is required for the maintenance of physiological conditions. A growing body of evidence suggests that both intracellular and compartmental zinc homeostasis is tightly controlled by the ZnT and ZIP families of transporter proteins. These crucial transporters are responsible for stabilizing intracellular zinc within cells [25]. The ZIP (SLC39A) family consists of 14 subtypes (ZIP1-14). They carry various metal ions including zinc into the cell cytoplasm from the lumen of organelles or across the membranes of cells (Table 1). The ZnT (SLC30A) family consists of 10 subtypes (ZnT1-10) that function in the efflux of cytoplasmic zinc into the lumen of organelles or into the intercellular space (Table 2). These transporters are either tissue specific or universally expressed in tissues depending on transporter subtype as summarized in Tables 1 and 2 and Figure 2. Dysregulation or the malfunction of these transporters leads to various diseases and subsequent abnormal zinc-mediated metabolism is a common link in the development of most cancers. 


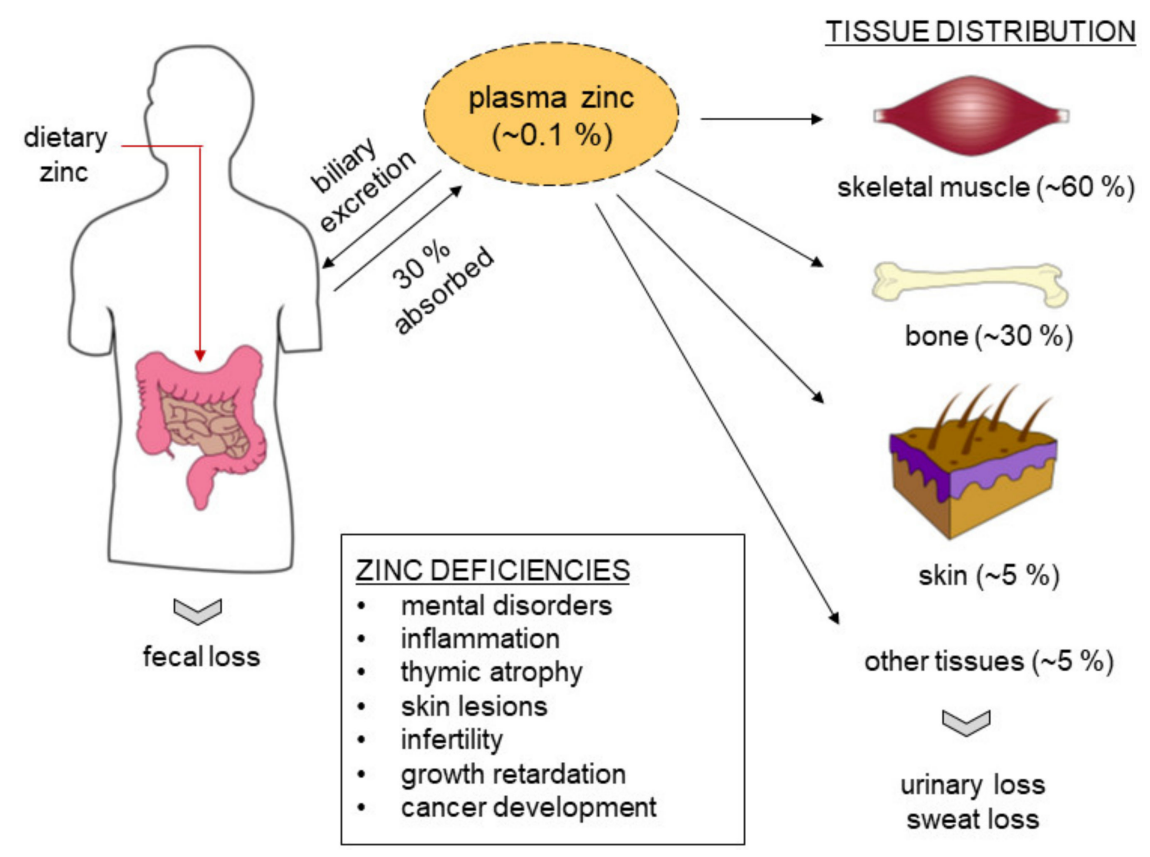

Figure 1. Zinc storage and distribution in the human body. The human body contains 2 to $3 \mathrm{~g}$ of zinc, which is absorbed by the duodenum and jejunum in the small intestine. Approximately $0.1 \%$ zinc is present in serum, $80 \%$ is loosely bound to albumin and approximately $20 \%$ is bound tightly to $\alpha 2$-macroglobulin. Approximately $60 \%$ of the zinc is stored in skeletal muscle, $30 \%$ in bone and approximately $5 \%$ in the skin and liver. The remaining zinc is distributed in other tissues, such as brain, kidneys, pancreas and heart. Zinc is excreted primarily through the gastrointestinal tract, with minor loss through urinary excretion.

Table 1. Human ZIP proteins.

\begin{tabular}{|c|c|c|c|c|}
\hline Protein & Gene Locus & Tissue/Cell Distribution & Subcellular Localization & References \\
\hline ZIP1/ZIRTL & $1 \mathrm{q} 21$ & wide spread & plasma membrane, & [26-28] \\
\hline ZIP2/Eti-1/6A1 & $14 q 11.1$ & wide spread & plasma membrane & [29-31] \\
\hline ZIP3 & 19 p13.3 & $\begin{array}{l}\text { wide spread, predominant } \\
\text { in testis }\end{array}$ & plasma membrane & {$[32,33]$} \\
\hline ZIP4 & $8 \mathrm{q} 24.3$ & $\begin{array}{l}\text { gastrointestinal tract, } \\
\text { kidney, hippocampal } \\
\text { neurons }\end{array}$ & plasma membrane & [34-36] \\
\hline ZIP5/LZT-Hs7 & $12 q 13.13$ & $\begin{array}{l}\text { pancreas, kidney, liver, } \\
\text { stomach, intestine }\end{array}$ & plasma membrane & [37-39] \\
\hline ZIP6/LIV1 & $18 \mathrm{q} 12.1$ & widespread & plasma membrane & {$[40,41]$} \\
\hline ZIP7/HKE4 & $6 \mathrm{p} 21.3$ & widespread & $\begin{array}{l}\text { ER, Golgi, intracellular } \\
\text { vesicles }\end{array}$ & {$[42-44]$} \\
\hline ZIP8/BIGM103/LZT-Hs6 & $4 q 22-q 24$ & $\begin{array}{l}\text { widespread, predominant } \\
\text { in pancreas }\end{array}$ & $\begin{array}{c}\text { plasma membrane, } \\
\text { lysosomes, endosomes, } \\
\text { mitochondria }\end{array}$ & {$[45,46]$} \\
\hline ZIP9 & $14 q 24.1$ & widespread & $\begin{array}{l}\text { plasma membrane, } \\
\text { trans-Golgi (TGN) }\end{array}$ & {$[47,48]$} \\
\hline ZIP10/LZT-Hs2 & $2 q 33.1$ & $\begin{array}{l}\text { brain, liver, erythroid, } \\
\text { kidney }\end{array}$ & plasma membrane & {$[40,49-51]$} \\
\hline ZIP11 & $17 q 25.1$ & testis, digestive system & $\begin{array}{l}\text { TGN, cytoplasm and } \\
\text { nuclei }\end{array}$ & {$[52,53]$} \\
\hline ZIP12 & 10p12.33 & brain, lung, testis, retina & plasma membrane, & {$[54,55]$} \\
\hline ZIP13 & 11p11.12 & widespread & intracellular vesicles, Golgi & {$[56,57]$} \\
\hline ZIP14 & $8 \mathrm{p} 21.2$ & widespread & $\begin{array}{l}\text { plasma membrane, } \\
\text { endosomes }\end{array}$ & [58-62] \\
\hline
\end{tabular}


Table 2. Human ZnT proteins.

\begin{tabular}{|c|c|c|c|c|}
\hline Protein & Gene Locus & Tissue/Cell Distribution & Subcellular Localization & References \\
\hline $\mathrm{ZnT1}$ & $1 \mathrm{q} 32.3$ & widespread & plasma membrane & {$[25,63,64]$} \\
\hline $\mathrm{ZnT2}$ & $1 \mathrm{p} 35.3$ & $\begin{array}{l}\text { mammary gland, prostate, } \\
\text { retina, pancreas, small } \\
\text { intestine, kidney }\end{array}$ & $\begin{array}{l}\text { plasma membrane, } \\
\text { endosomes, lysosomes, } \\
\text { secretory vesicles and } \\
\text { mitochondria }\end{array}$ & [65-68] \\
\hline $\mathrm{ZnT3}$ & $2 \mathrm{p} 23.3$ & brain, testes, pancreas & synaptic vesicles & [69-72] \\
\hline ZnT4/ Dri27 & $15 \mathrm{q} 21.1$ & $\begin{array}{l}\text { widespread, predominant } \\
\text { in mammary gland, } \\
\text { placenta, prostate, brain } \\
\text { and kidney }\end{array}$ & $\begin{array}{c}\text { plasma membrane, } \\
\text { endosomes, secretory } \\
\text { vesicles }\end{array}$ & [73-75] \\
\hline ZnT5/ ZTL1 & $5 q 13.1$ & $\begin{array}{l}\text { widespread, predominant } \\
\text { in pancreas, liver. kidney }\end{array}$ & TGN, plasma membrane & [76-78] \\
\hline ZnT6 & $2 p 22.3$ & $\begin{array}{l}\text { widespread } \\
\text { widespread, enriched in }\end{array}$ & TGN, unknown vesicles & {$[79,80]$} \\
\hline ZnT7 & $1 \mathrm{p} 21.2$ & $\begin{array}{l}\text { stomach, prostate, retina, } \\
\text { pancreas, testis and muscle }\end{array}$ & Golgi, unknown vesicles & [81-83] \\
\hline ZnT8 & $1 \mathrm{q} 41$ & $\begin{array}{l}\text { pancreas, thyroid, adrenal } \\
\text { gland, testis }\end{array}$ & secretory vesicles & [84-86] \\
\hline ZnT9/C4orf1 & $4 \mathrm{p} 13$ & widespread & cytoplasm, nucleus & {$[87,88]$} \\
\hline ZnT10 & $1 \mathrm{q} 41$ & brain, retina, liver & $\begin{array}{l}\text { endosomes, endosomes, } \\
\text { plasma membrane }\end{array}$ & [89-91] \\
\hline
\end{tabular}

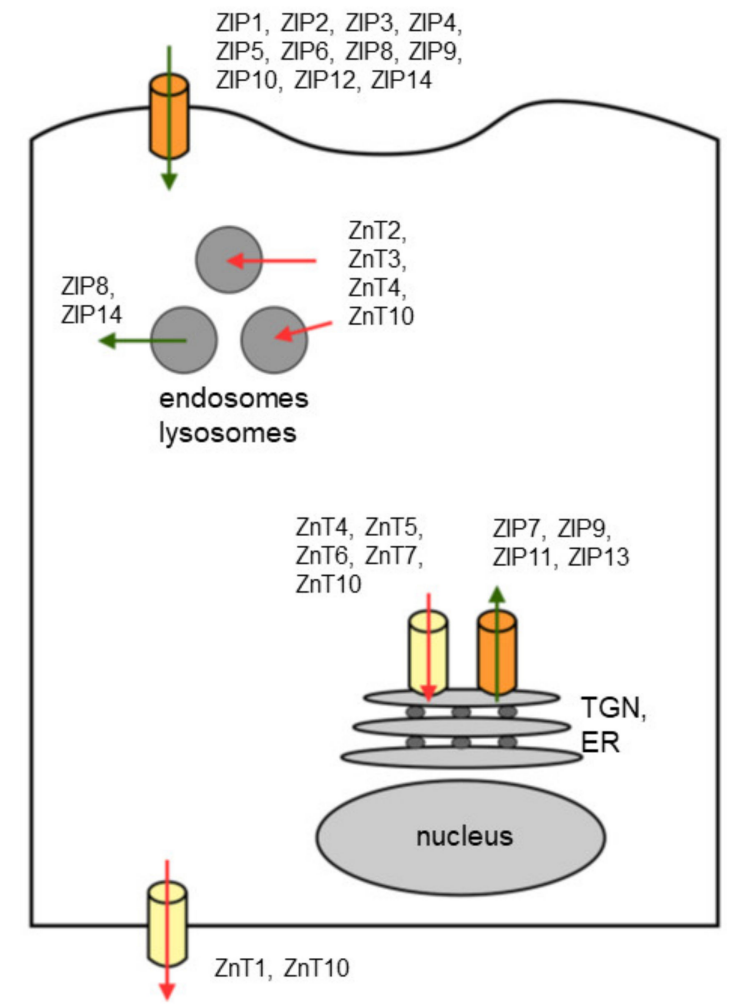

Figure 2. Zinc transporters and their subcellular localization. Subcellular localization of ZIP (green arrow) and ZnT (red arrow) is shown based on currently available information. The cytosolic zinc is mobilized into or out of different subcellular compartments, as indicated with arrows. Abbreviations are: TGN, trans-Golgi network; ER, endoplasmic reticulum.

\section{Zinc and Zinc Transporters in Prostate Cancer}

Zinc has long been known to be highly concentrated in prostate tissue-more than 10 times enriched compared to that in other soft tissues [92]. Analysis of frozen prostate tissues demonstrated lower levels of zinc in prostate carcinoma compared to those in normal prostate [93]. Zinc content of 1018, 1142 and $146 \mu \mathrm{g} / \mathrm{g}$ dry weight in normal prostate, benign prostatic hyperplasia (BPH) and prostate carcinoma tissue, respectively, was reported [94]. Zinc concentration in malignant prostate is 
approximately $10 \%$ to $25 \%$ lower than that of normal prostate [95]. Zinc contents in plasma are also significantly lower in prostate carcinoma $(27 \%)$ and $\mathrm{BPH}(18 \%)$ compared to those in normal prostate samples [96]. A meta-analysis documented significantly lower levels of zinc in prostate cancers than in benign tumors and normal prostates [97]. Taken together, these findings indicate that the development of prostate malignancy is strongly associated with the reduction of intracellular zinc in malignant cells and the circulating level in plasma.

As the alteration of zinc homeostasis is controlled by cellular zinc transporters, many efforts have made to examine how intracellular zinc is regulated through zinc transporters [98-100]. Zinc trafficking requires specialized plasma membrane transporters. Their dysregulation causes abnormal growth of the prostate, including cancer. It is not well understood why prostate cancer cells depress cellular zinc levels. One proposed explanation is that the transformation of citrate producing normal cells to citrate-oxidizing malignant cells leads to the loss of the ability of the cells to accumulate zinc [95]. In addition, a genetic alteration in the expression of zinc transporters is associated with this metabolic transformation.

ZIP1, a member of the ZIP (SLC39) family, carries zinc or other metal ions from the extracellular space and/or intracellular organelles to the cytoplasm [2]. During prostatic cell transformation, the level of ZIP1 was remarkably decreased or absent compared to that in BHP or normal prostate [101]. Comparison of RWPE1 non-tumorigenic human prostate cells with its RWPE2 tumorigenic counterpart revealed the markedly lower zinc uptake in RWPE2 cells than in RWPE1 cells (33\% decrease) and the downregulated expression of ZIP1 protein in RWPE2 cells [102]. Another comparison of the transgenic adenocarcinoma of the mouse prostate (TRAMP) model to wild type mice demonstrated the markedly lower zinc level and loss of ZIP1 expression in the prostate gland of TRAMP mice [103]. In LNCaP and PC3 prostate cancer cell lines, ZIP1 is the major zinc uptake transporter [104]. Forced expression of ZIP1 in these cells stimulated intracellular accumulation of zinc and inhibited cell proliferation due to increased apoptosis [26]. ZIP2 serves as another zinc uptake transporter across the plasma membrane and low levels of ZIP2 are restricted to a few tissues, including prostate and uterine glands [105]. Both ZIP2 and ZIP3 share a similar function with their ZIP1. Both were downregulated in malignant prostate cells and associated with the loss of zinc accumulation in tumor cells [106]. ZIP4 is also involved in zinc influx and is reduced in cancer tissues [107]. Despite the general reduction of ZIP proteins in prostate cancers, a correlation between the expression levels of most ZIP subspecies and cancer grade has not been established.

In contrast to the zinc influx protein family, zinc efflux transporters seem to be less involved in the transformation of the prostate gland and consequently have been less studied. In one study, ZnT1 expression was decreased or remained unchanged in prostate cancers than in BPH [108]. Decreased expression of ZnT4 was observed during the progression of prostate cancers, being under-expressed in both localized and metastatic prostate cancers compared to that in benign tissues [109]. ZnT4 expression was reportedly localized in intracellular vesicles and plasma membranes. At the RNA level, ZnT1, ZnT9 and ZnT10 were significantly upregulated in human prostate cancer tissues compared to those in adjacent normal tissues, implying that intracellular zinc is diminished through this upregulation of zinc output transporters [110]. ZnT7 null-mutation in TRAMP mice was reported to accelerate the formation of prostate tumors compared to that in TRAMP mice retaining wild type ZnT7 [111]. Expression of other zinc input transporters, including ZnT2, ZnT3, ZnT5, ZnT6 and ZnT8, has not been fully described and detailed studies are still ongoing. For now, there is not a clear understanding of zinc equilibrium.

Prostate specific antigen (PSA) is highly expressed in LNCaP cells. This can facilitate LNCaP cell invasion by degrading the extracellular matrix fibronectin and laminin glycoproteins [112]. Zinc strongly inhibited the enzymatic activity of PSA and suppressed the invasion of LNCaP cells, suggesting that zinc inhibits malignant prostate cancer cell invasion [113]. Physiological levels of zinc $(0.25-0.5 \mu \mathrm{g} / \mathrm{mL})$ inhibit nuclear factor-kappa B (NF- $\mathrm{kB}$ ) activities by reducing RelA activity induced by tumor necrosis factor-alpha (TNF- $\alpha$ ) and scaling down the expression of cellular inhibitors of 
apoptosis protein 2 (c-IAP2) in highly invasive androgen-independent DU145 and PC3 prostate cancer cell lines [114]. Furthermore, the zinc-reduced expression of vascular endothelial growth factor (VEGF), interleukin (IL)-6, IL-8 and matrix metalloproteinase-9 (MMP-9), which have been generally identified as pro-angiogenic and pro-metastatic molecules. Zinc can also diminish the expression of intercellular adhesion molecule-1 (ICAM1) to suppress tumor cell invasion and adhesion [115]. Homeobox B13 (HOXB13), a DNA-binding transcription factor, is overexpressed in castration-resistant prostate cancer and causes the zinc concentration to fall. This decrease subsequently stimulates cancer invasion and metastasis by promoting NF- $\mathrm{kB}$ signaling, through the reduction of NF- $\mathrm{kB}$ inhibitor $(\mathrm{I} \kappa \mathrm{B} \alpha)$ [116]. HOXB13-mediated suppression of zinc is accomplished through the stimulation of the expression of the ZnT4 zinc efflux transporter but does not affect input transporters. These results indicate that the loss of intracellular zinc could enhance HOXB13 expression in prostate cancer, leading to the stimulation of the NF- $\mathrm{kB}$ signaling pathway to promote prostate cancer metastasis. Zinc also affects the activity of urokinase-type plasminogen activator (uPA) and aminopeptidase N (AP-N) to suppress the invasion and metastasis of PC-3 prostate cancer cells [117]. The collective findings strongly indicate that excess quantities of zinc negatively regulate prostate cancer cell growth, invasion and metastasis.

\section{Zinc and Zinc Transporters in Other Cancers}

Whereas serum zinc levels are low during breast cancer development [118,119], biopsies from breast cancer patients have revealed significantly higher zinc levels compared with those in normal breast tissues [120-122]. Correspondingly, the expression of zinc transporters, including ZIP6, ZIP7 and ZIP10, were positively correlated with the risk of breast cancer [123]. The involvement of ZIP6 in longer relapse free survival and prolonged survival of breast cancer patients with ductal carcinoma invasion has been documented [124]. Knockdown of ZIP6 in MCF-7 breast cancer cells can increase cell survival in hypoxic environments [125,126]. ZIP6 also reportedly promotes breast cancer cell invasion and metastasis, together with the high expression of E-cadherin [127,128]. Upregulation of ZIP7 was reported in high risk breast cancer and was linked to a poor prognosis [129]. ZIP6 expression was positively correlated with estrogen receptor (ER) and correlated with aggressive breast cancer with promoted metastasis $[130,131]$. More than $70 \%$ of breast cancer cells are characterized as ER positive $(\mathrm{ER}+)$ and anti-estrogen compounds are among the main therapeutic drugs for ER+ breast cancer cells. Unfortunately, the efficacy of the anti-estrogen drug tamoxifen for malignant breast cancer is limited due to the emergence of estrogen-independent breast cancers [132,133]. ZIP6 has been associated with higher zinc levels in breast tumor cells compared with those in normal breast cells and anti-estrogen compounds can reduce cellular zinc pools [134]. Zinc and ZIP7 was increased in tamoxifen resistance MCF-7 cells, which enhanced growth factor activity and induced cancer cell growth and invasion [135]. Suppression of ZIP7 can repress epidermal growth factor receptor signaling, which subsequently reduces tumor cell growth and prevents the acquisition of breast cancer resistance to tamoxifen. These results suggest that abnormal regulation of ZIP6 and ZIP7 and intracellular zinc contents are strongly involved in breast cancer cell proliferation and migration. ZIP10 expression was reportedly significantly higher in highly invasive and metastatic breast cancer cells (MDA-MB-231 and MDA-MB-435S) than in less metastatic breast cancer cells (MCF7, T47D, ZR75-1 and ZR75-30). Accordingly, ZIP10 was associated with lymph node metastasis of breast cancer; the suppression of ZIP10 can inhibit the migration of breast cancer cells [49].

Dysregulation of zinc and zinc transporters have also been considered as the major factors for progression of pancreatic cancer. ZIP3 and ZIP4 are two well-studied transporters that display altered expression in pancreatic tumor tissues. One study described the loss of zinc in ductal and acinar epithelium of pancreatic cancers in which ZIP3 expression was downregulated compared with that in normal pancreatic epithelium [136]. ZIP4 is reportedly overexpressed in $94 \%$ of pancreatic adenocarcinomas compared with that in surrounding normal tissues [137]. The forced expression of ZIP4 increased intracellular zinc levels, increased cell proliferation and dramatically increased tumor volume in nude mice, suggesting that zinc availability and aberrant ZIP4 expression might be essential 
for pancreatic tumor growth. In esophageal cancers, markedly lower plasma zinc levels as compared to the levels in esophagitis and normal groups were described [138]. Another study described the overexpression of ZIP5 in esophageal squamous cell carcinoma compared to that in normal tissue and that knockdown of ZIP5 reduced cell proliferation, migration and invasion due to the suppression of COX2 and cyclin D1 [139]. In NCI-H358 lung cancer cells, ZIP1, ZIP4, ZIP7 and ZIP10 were all elevated, with ZIP4 expression being highest. Although the expression of ZnTs was generally low, ZnT7 and ZnT9 were significantly overexpressed in lung tumor tissues [140]. In bladder cancers, ZnT1 was overexpressed and suppression of ZnT1 led to the inhibition of the proliferation, migration and invasion in BIU87 bladder cancer cells [141]. In hepatocellular cancer, zinc was lost in 55\% of hepatocellular cancers [142]. Increasing numbers of reports suggest that the abnormal regulation of zinc is involved in many cancers, including prostate, breast and pancreatic cancers. The pattern of zinc alteration is somewhat tissue specific and zinc generally induces inhibition of cancer cell growth by targeting the intrinsic apoptotic pathway. Although the mechanisms of how zinc dysregulation drive cancer development are not very well established, the expression of zinc transporters are commonly altered in multiple cancers and these transports have been implicated in this process.

\section{Zinc as an Agent for Treatment of Prostate Cancer}

The human body contains over $2 \mathrm{~g}$ of zinc with the highest content present in the prostate [143]. The total cellular zinc concentration for most mammalian cells typically ranges from 100 to $500 \mu \mathrm{M}$ [144, 145]. However, zinc is concentrated in epithelial cells in the peripheral zone of the prostate in the range of 800 to $1500 \mu \mathrm{M}$ [146]. Only limited bioavailable free zinc is available [2,93,95,101,147,148]. The distribution of zinc in the cells is approximately $30 \%$ to $40 \%$ in the nucleus, $50 \%$ in the cytoplasm, with the remainder in the cell membrane $[149,150]$. At the same time, the total intracellular zinc $(0.2-1 \mathrm{mM})$ is divided into three pools, including tightly bound zinc as an immobile and unreactive pool, loosely bound zinc and a reactive pool of free zinc ion. Approximately $90 \%$ of cytoplasmic zinc is bound to immobile macromolecules, mostly proteins, with $10 \%$ bound to mobile low molecular weight ligands [151]. As previously mentioned, the content of zinc in prostate carcinoma is much lower than that in normal prostatic epithelial cells [93]. Zinc deficiency in prostate cancer cells has led to the central dogma that the supplementation of zinc may contribute to the prevention of prostate cancer as well as halting cancer malignancy. The re-introduction of physiological levels of zinc into cancer cells has yielded diverse results that have challenged the interpretation of the biologic functions of zinc. Low doses of zinc may not reach the biological threshold, while at higher doses zinc may become ineffective due to its toxicity [152]. Therefore, most therapeutic studies have been done using excessive amounts of zinc due to the aforementioned cellular distribution of zinc. Table 3 summarizes several prostate cancer therapeutic studies previously performed using various doses of zinc in vitro and in vivo. Effective growth inhibition for LNCaP cells was accomplished at $100 \mathrm{ng} / \mathrm{mL}$ zinc, whereas a higher concentration $(700 \mathrm{ng} / \mathrm{mL})$ was required to show similar growth inhibition in PC-3 cells [153]. Zinc-mediated growth inhibition was accomplished through the induction of apoptosis, arrest of cells in the G2/M phase of the cell cycle and zinc-mediated increased expression of p21 Waf1/Cip1/Sdi1. Zinc treatment also released cytochrome $\mathrm{c}$ from mitochondria to cytosol, activated caspase 3 and 9 and cleaved nuclear poly (ADP)-ribose polymerase (PARP), which activated apoptosis in malignant prostate cancer cells $[154,155]$. The growth of most prostate cancer cells, including LNCaP, DU145 and PC-3, can be inhibited by the addition of $\mathrm{ZnSO}_{4}$ in a range from 200 to $600 \mu \mathrm{M}[156,157]$. Zinc also inhibits hypoxia inducible factor-1 alpha (HIF1 $\alpha$ ) expression and its activity to repress cancer stimulating pathways, such as VEGF and Bcl2 [158]. In addition, zinc contributes to the truncation of the Krebs cycle and inhibition of citrate oxidation, which further prevents cancer cell growth and proliferation, as well as inhibiting the invasion and migration of cancer cells [95]. 
Table 3. Various strategies for prostate cancer therapeutics with zinc.

\begin{tabular}{|c|c|c|c|c|c|}
\hline Cells & Animals & Zinc Dosages & Delivery & Effects & References \\
\hline PC3, LNCaP & in vitro & up to $1 \mu \mathrm{g} / \mathrm{mL} \mathrm{ZnSO}_{4}$ & culture media & $\begin{array}{l}\text { Inhibition of cell growth: induction of } \\
\text { apoptosis by G2/M arrest and increase of } \\
\text { p21 Waf//ip1/Sdil expression }\end{array}$ & [153-155] \\
\hline PC3, LNCaP & in vitro & 50-150 $\mu \mathrm{M}$ zinc acetate & matrigel & $\begin{array}{l}\text { Inhibition of cell invasion: Suppression of } \\
\text { PSA and uPA activities }\end{array}$ & {$[113,159]$} \\
\hline PC-3, DU145 & in vitro & $0.06-0.55 \mu \mathrm{g} / \mathrm{mL} \mathrm{ZnSO}_{4}$ & culture media & $\begin{array}{l}\text { Inhibition of cell metastasis by regulation } \\
\text { NF-kB and c-IAP2 activities; stimulation of } \\
\text { AP-1; suppressed expression of VEGF, IL-6, } \\
\text { IL-8 and MMP-9 }\end{array}$ & {$[114,115]$} \\
\hline $\mathrm{PC}^{\mathrm{ZIP} 1}$ & in vitro; C.B.17 SCID mice & $1.5 \mu \mathrm{g} / \mathrm{mL} \mathrm{ZnSO}_{4} ; 2000 \mathrm{ppm} \mathrm{ZnSO}_{4}$ & $\begin{array}{l}\text { culture media; drinking } \\
\text { water }\end{array}$ & $\begin{array}{l}\text { Overexpression of ZIP1 reduced cell growth } \\
\text { and invasion by Inhibition of NF-kB activity }\end{array}$ & {$[114,115,160]$} \\
\hline PC3 & NOD/SCID mice & $200 \mu \mathrm{L}$ of $3 \mathrm{mM}$ zinc acetate & intratumoral injection & $\begin{array}{l}\text { Inhibition of tumor growth enhancement of } \\
\text { animal survival }\end{array}$ & [157] \\
\hline PC3 & NOD/SCID mice & $3-20 \mathrm{mg} / \mathrm{kg} \mathrm{ZnCl}{ }_{2}$ & intraperitoneal injection & No effects on xenograft tumor cell growth & [161] \\
\hline PC3 & nude mice & $\mathrm{ZnSO}_{4}(30-45 \mu \mathrm{g} /$ day $)$ for 28 days & osmotic pumps & $\begin{array}{l}\text { Inhibition of tumor growth by increased } \\
\mathrm{Bax} / \mathrm{Bcl}-2 \text { protein expression }\end{array}$ & [162] \\
\hline Transgenic prostate cancer & TRAMP mice & $\begin{array}{l}0.85,30, \text { or } 150 \mathrm{ppm} \text { zinc carbonate } \\
(52.1 \% \mathrm{Zn}) \text { for } 22 \text { weeks }\end{array}$ & pellet & $\begin{array}{l}\text { Increased tumor weights upon deficient or } \\
\text { high zinc uptake }\end{array}$ & [163] \\
\hline TRAMP-C2 & C57BL/6 mice & $10 \mathrm{mg} / \mathrm{kg} \mathrm{ZnCl} 2$ for 2 weeks & intraperitoneal injection & $\begin{array}{l}\text { Repressed tumor growth and androgen } \\
\text { receptor expression }\end{array}$ & [164] \\
\hline $\begin{array}{c}\text { MNU and } \\
\text { testosterone-induced PIN }\end{array}$ & Sprague Dawley rat & $100 \mathrm{ppm} \mathrm{ZnCl}_{2}$ for 20 weeks & drinking water & $\begin{array}{l}\text { Reverse effects on MNU and } \\
\text { testosterone-mediated PIN }\end{array}$ & [165] \\
\hline
\end{tabular}

PSA, prostate specific antigen; uPA, urokinase-type plasminogen activator; c-IAP2, cellular inhibitors of apoptosis protein 2; TRAMP, transgenic adenocarcinoma mouse prostate, MNU, $\mathrm{N}$-methyl-N-nitrosourea; PIN, prostatic intraepithelial neoplasia. 
Many in vivo studies have verified that zinc efficiently suppresses prostate cancer tumors. When zinc was administered to PC-3 cell-bearing nude mice by osmotic pumps for 4 weeks, tumor growth was markedly reduced with the intracellular accumulation of zinc, followed by the elevated expression of the apoptosis-induced protein Bax/Bcl-2 [162]. Direct injection of 200 to $600 \mu \mathrm{M}$ zinc into mice-bearing PC 3 tumors halted growth of the tumors and subsequently extended the survival of the animals, with no detectable cytotoxicity to other tissues [157]. Furthermore, the intraperitoneal injection of TRAMP-C2 bearing mice with $10 \mathrm{mg} / \mathrm{kg}$ body weight zinc led to the remarkable decrease of tumor volume with the reduced expression of androgen receptor [164]. A study using various doses of zinc in TRAMP mice as an attempt to investigate the chemopreventative potential of zinc showed that a zinc-sufficient diet protected tumor development in the mice [163]. Administration of $100 \mathrm{ppm}$ (or $0.01 \%$ ) of zinc in drinking water for 20 weeks reversed the various effects induced by carcinogenic N-methyl-N-nitrosourea combined with testosterone [165]. These effects included tumor formation, phosphatase activity and expression of p53, Bcl-2 and caspase-3 on the dorsolateral prostate of rats, implicating zinc in protecting from carcinogen-induced tumor progression. In a clinical study involving nearly 700 patients with prostate cancer, adequate uptake of zinc was associated with a reduced risk of prostate cancer [166]. A study involving 525 men with prostate cancer in Sweden also showed that a high zinc diet reduced the risk of prostate cancers [167]. Although the majority of studies supported the hypothesis that zinc intake by cancer cells can prevent growth of the cells $[146,153,168]$, other studies reported that zinc supplementation was neutral or detrimental to prostate cancer progression $[169,170]$. For example, evaluation of the influence of zinc treatment on cancer risk in the VITamins And Lifestyle (VITAL) cohort revealed that 10 years consumption of a zinc diet did not reduce prostate cancer risk, while the intake of an average intake of $>15 \mathrm{mg} /$ day of zinc decreased risk of advanced prostate cancer [171]. A large epidemiological study performed by the United States National Cancer Institute suggested that supplemental zinc intake at doses of $100 \mathrm{mg} /$ day for 14 years was not associated with prostate cancer risk, although a higher risk of advanced prostate cancer was evident in a small group of individuals [172].

\section{Perspective}

For many years, extensive investigations to decipher the precise role(s) of zinc ion have been conducted in both normal and cancer cells. Zinc is an essential component for all forms of life and is a crucial trace element required for the activity of more than 300 enzymes. Over 2000 zinc-finger transcription factors are deeply involved in growth-modulating cell signaling pathways. Consequently, zinc deficiency is responsible for the development of various diseases, such as abnormal body growth, immune dysfunction, diabetes and cancers. Loss of zinc has been documented in patients diagnosed with a variety of cancer types, including prostate cancer, hepatocellular cancer, pancreatic cancer, lung cancer, ovarian cancer, esophageal squamous cell carcinoma and breast cancer. Among all soft tissues, the prostate is most enriched in zinc. Decrease in intracellular zinc is a feature of prostate cancer development and even progression to malignancy. The diverse functions of zinc in prostate cancer include inhibition of cell proliferation by induction of the cell cycle and the inhibition of cell migration and invasion. Zinc and zinc derivatives have been extensively studied to test the hypothesis that therapies that lead to the accumulation of zinc in cancer cells effectively inhibit the proliferation of these cells. A great deal of experimental evidence supports the idea that zinc derivatives and zinc supplements are able to suppress the proliferation, migration and invasion of prostate cancer cells. Moreover, the appropriate intake of zinc into cancer cells can reduce the risk of prostate cancer. However, the efficacy of zinc provided in any form seems to be limited mainly due to the inability of cancer cells to import excessive zinc from the extracellular milieu. Hence, many ongoing studies have explored the relationship between zinc and functional zinc transporters, such as ZIP1, which is lost or decreased in many prostate cancers. There are also many conflicting results concerning the curative and preventative roles of zinc in prostate cancers. Several epidemiologic studies have suggested that zinc supplementation may increase the risk of advanced prostate cancer. The inconsistency in data 
concerning dietary zinc supplementation and the zinc-related impact on prostate cancer prevention and treatment has cast suspicion on zinc-mediated therapies. This issue needs to be extensively investigated. Understanding the mechanism by which zinc is lost during prostate malignancy and detailed information underlying the protective role of zinc in prostate cancer will help to address its importance in the malignancy and progression of prostate cancer and thus the value of zinc in prostate cancer prevention and therapy.

Funding: This work was supported by Basic Science Research Programs through the National Research Foundation of Korea (2016R1D1A3B04933830 and 2019R1A2C1004668) funded by the Ministry of Science, ICT and Future Planning.

Conflicts of Interest: The authors declare no conflicts of interest. The funders had no role in the design of the study; in the collection, analyses, or interpretation of data; in the writing of the manuscript, or in the decision to publish the results.

\section{References}

1. Roohani, N.; Hurrell, R.; Kelishadi, R.; Schulin, R. Zinc and its importance for human health: An integrative review. J. Res. Med. Sci. 2013, 18, 144-157. [PubMed]

2. Eide, D.J. Zinc transporters and the cellular trafficking of zinc. Biochim. et Biophys. Acta 2006, 1763, 711-722. [CrossRef] [PubMed]

3. Andreini, C.; Banci, L.; Bertini, I.; Rosato, A. Counting the zinc-proteins encoded in the human genome. J. Proteome Res. 2006, 5, 196-201. [CrossRef] [PubMed]

4. Rink, L.; Gabriel, P. Zinc and the immune system. Proc. Nutr. Soc. 2000, 59, 541-552. [CrossRef] [PubMed]

5. Murakami, M.; Hirano, T. Intracellular zinc homeostasis and zinc signaling. Cancer Sci. 2008, 99, 1515-1522. [CrossRef]

6. John, E.; Laskow, T.C.; Buchser, W.J.; Pitt, B.R.; Basse, P.H.; Butterfield, L.H.; Kalinski, P.; Lotze, M.T. Zinc in innate and adaptive tumor immunity. J. Transl. Med. 2010, 8, 118. [CrossRef]

7. Duncan, J.R.; Hurley, L.S. Thymidine kinase and DNA polymerase activity in normal and zinc deficient developing rat embryos. Proc. Soc. Exp. Biol. Med. 1978, 159, 39-43. [CrossRef]

8. Wu, F.Y.; Wu, C.W. Zinc in DNA replication and transcription. Annu. Rev. Nutr. 1987, 7, 251-272. [CrossRef]

9. Song, Y.; Leonard, S.W.; Traber, M.G.; Ho, E. Zinc deficiency affects DNA damage, oxidative stress, antioxidant defenses and DNA repair in rats. J. Nutr. 2009, 139, 1626-1631. [CrossRef]

10. Ho, E. Zinc deficiency, DNA damage and cancer risk. J. Nutr. Biochem. 2004, 15, 572-578. [CrossRef]

11. Sliwinski, T.; Czechowska, A.; Kolodziejczak, M.; Jajte, J.; Wisniewska-Jarosinska, M.; Blasiak, J. Zinc salts differentially modulate DNA damage in normal and cancer cells. Cell Biol. Int. 2009, 33, 542-547. [CrossRef] [PubMed]

12. Yan, M.; Song, Y.; Wong, C.P.; Hardin, K.; Ho, E. Zinc deficiency alters DNA damage response genes in normal human prostate epithelial cells. J. Nutr. 2008, 138, 667-673. [CrossRef] [PubMed]

13. Roth, H.P.; Kirchgessner, M. Influence of alimentary zinc deficiency on the concentration of growth hormone (gh), insulin-like growth factor i (igf-i) and insulin in the serum of force-fed rats. Horm. Metab. Res. 1994, 26, 404-408. [CrossRef] [PubMed]

14. Huang, J.S.; Mukherjee, J.J.; Chung, T.; Crilly, K.S.; Kiss, Z. Extracellular calcium stimulates DNA synthesis in synergism with zinc, insulin and insulin-like growth factor i in fibroblasts. Eur. J. Biochem. 1999, 266, 943-951. [CrossRef] [PubMed]

15. Chesters, J.K.; Boyne, R. Nature of the zn2+ requirement for DNA synthesis by $3 \mathrm{t} 3$ cells. Exp. Cell Res. 1991, 192, 631-634. [CrossRef]

16. Wong, S.H.; Shih, R.S.; Schoene, N.W.; Lei, K.Y. Zinc-induced g2/m blockage is p53 and p21 dependent in normal human bronchial epithelial cells. Am. J. Physiol. Cell Physiol. 2008, 294, C1342-C1349. [CrossRef] [PubMed]

17. Jackson, M.A.; Slininger, P.J.; Bothast, R.J. Effects of zinc, iron, cobalt and manganese on fusarium moniliforme nrrl 13616 growth and fusarin c biosynthesis in submerged cultures. Appl. Environ. Microbiol. 1989, 55, 649-655. [CrossRef]

18. King, J.C.; Shames, D.M.; Woodhouse, L.R. Zinc homeostasis in humans. J. Nutr. 2000, 130, 1360S-1366S. [CrossRef] 
19. Kambe, T.; Hashimoto, A.; Fujimoto, S. Current understanding of zip and znt zinc transporters in human health and diseases. Cell Mol. Life Sci. 2014, 71, 3281-3295. [CrossRef]

20. Liuzzi, J.P.; Cousins, R.J. Mammalian zinc transporters. Annu. Rev. Nutr. 2004, 24, 151-172. [CrossRef]

21. Bafaro, E.; Liu, Y.; Xu, Y.; Dempski, R.E. The emerging role of zinc transporters in cellular homeostasis and cancer. Signal. Transduct Target. Ther. 2017, 2. [CrossRef]

22. Pan, Z.; Choi, S.; Ouadid-Ahidouch, H.; Yang, J.M.; Beattie, J.H.; Korichneva, I. Zinc transporters and dysregulated channels in cancers. Front. Biosci. (Landmark Ed.) 2017, 22, 623-643. [CrossRef]

23. Maret, W. Zinc and human disease. Met. Ions Life Sci. 2013, 13, 389-414.

24. Danscher, G.; Stoltenberg, M. Zinc-specific autometallographic in vivo selenium methods: Tracing of zinc-enriched (zen) terminals, zen pathways and pools of zinc ions in a multitude of other zen cells. J. Histochem. Cytochem. 2005, 53, 141-153. [CrossRef]

25. Cousins, R.J.; Liuzzi, J.P.; Lichten, L.A. Mammalian zinc transport, trafficking and signals. J. Biol. Chem. 2006, 281, 24085-24089. [CrossRef]

26. Franklin, R.B.; Ma, J.; Zou, J.; Guan, Z.; Kukoyi, B.I.; Feng, P.; Costello, L.C. Human zip1 is a major zinc uptake transporter for the accumulation of zinc in prostate cells. J. Inorg Biochem. 2003, 96, 435-442. [CrossRef]

27. Gaither, L.A.; Eide, D.J. The human zip1 transporter mediates zinc uptake in human k562 erythroleukemia cells. J. Biol. Chem. 2001, 276, 22258-22264. [CrossRef]

28. Milon, B.; Dhermy, D.; Pountney, D.; Bourgeois, M.; Beaumont, C. Differential subcellular localization of hzip1 in adherent and non-adherent cells. FEBS Lett. 2001, 507, 241-246. [CrossRef]

29. Cao, J.; Bobo, J.A.; Liuzzi, J.P.; Cousins, R.J. Effects of intracellular zinc depletion on metallothionein and zip2 transporter expression and apoptosis. J. Leukoc. Biol. 2001, 70, 559-566.

30. Gaither, L.A.; Eide, D.J. Functional expression of the human hzip2 zinc transporter. J. Biol. Chem. 2000, 275, 5560-5564. [CrossRef]

31. Peters, J.L.; Dufner-Beattie, J.; Xu, W.; Geiser, J.; Lahner, B.; Salt, D.E.; Andrews, G.K. Targeting of the mouse slc39a2 (zip2) gene reveals highly cell-specific patterns of expression and unique functions in zinc, iron and calcium homeostasis. Genesis 2007, 45, 339-352. [CrossRef]

32. Costello, L.C.; Zou, J.; Desouki, M.M.; Franklin, R.B. Evidence for changes in rreb-1, zip3 and zinc in the early development of pancreatic adenocarcinoma. J. Gastrointest Cancer 2012, 43, 570-578. [CrossRef] [PubMed]

33. Dufner-Beattie, J.; Huang, Z.L.; Geiser, J.; Xu, W.; Andrews, G.K. Generation and characterization of mice lacking the zinc uptake transporter zip3. Mol. Cell Biol. 2005, 25, 5607-5615. [CrossRef] [PubMed]

34. Dufner-Beattie, J.; Langmade, S.J.; Wang, F.; Eide, D.; Andrews, G.K. Structure, function and regulation of a subfamily of mouse zinc transporter genes. J. Biol. Chem. 2003, 278, 50142-50150. [CrossRef] [PubMed]

35. Wang, F.; Kim, B.E.; Dufner-Beattie, J.; Petris, M.J.; Andrews, G.; Eide, D.J. Acrodermatitis enteropathica mutations affect transport activity, localization and zinc-responsive trafficking of the mouse zip4 zinc transporter. Human Mol. Genet. 2004, 13, 563-571. [CrossRef] [PubMed]

36. Wang, K.; Zhou, B.; Kuo, Y.M.; Zemansky, J.; Gitschier, J. A novel member of a zinc transporter family is defective in acrodermatitis enteropathica. Am. J. Human Genet. 2002, 71, 66-73. [CrossRef]

37. Dufner-Beattie, J.; Kuo, Y.M.; Gitschier, J.; Andrews, G.K. The adaptive response to dietary zinc in mice involves the differential cellular localization and zinc regulation of the zinc transporters zip4 and zip5. J. Biol. Chem. 2004, 279, 49082-49090. [CrossRef]

38. Wang, F.; Kim, B.E.; Petris, M.J.; Eide, D.J. The mammalian zip5 protein is a zinc transporter that localizes to the basolateral surface of polarized cells. J. Biol. Chem. 2004, 279, 51433-51441. [CrossRef]

39. Yang, J.; Zhang, Y.; Cui, X.; Yao, W.; Yu, X.; Cen, P.; Hodges, S.E.; Fisher, W.E.; Brunicardi, F.C.; Chen, C.; et al. Gene profile identifies zinc transporters differentially expressed in normal human organs and human pancreatic cancer. Curr. Mol. Med. 2013, 13, 401-409.

40. Croxford, T.P.; McCormick, N.H.; Kelleher, S.L. Moderate zinc deficiency reduces testicular zip6 and zip10 abundance and impairs spermatogenesis in mice. J. Nutr. 2011, 141, 359-365. [CrossRef]

41. Liu, Y.; Batchuluun, B.; Ho, L.; Zhu, D.; Prentice, K.J.; Bhattacharjee, A.; Zhang, M.; Pourasgari, F.; Hardy, A.B.; Taylor, K.M.; et al. Characterization of zinc influx transporters (zips) in pancreatic beta cells: Roles in regulating cytosolic zinc homeostasis and insulin secretion. J. Biol. Chem. 2015, 290, 18757-18769. [CrossRef]

42. Hogstrand, C.; Kille, P.; Nicholson, R.I.; Taylor, K.M. Zinc transporters and cancer: A potential role for zip7 as a hub for tyrosine kinase activation. Trends Mol. Med. 2009, 15, 101-111. [CrossRef] 
43. Huang, L.; Kirschke, C.P.; Zhang, Y.; Yu, Y.Y. The zip7 gene (slc39a7) encodes a zinc transporter involved in zinc homeostasis of the golgi apparatus. J. Biol. Chem. 2005, 280, 15456-15463. [CrossRef]

44. Taylor, K.M.; Morgan, H.E.; Johnson, A.; Nicholson, R.I. Structure-function analysis of hke4, a member of the new liv-1 subfamily of zinc transporters. Biochem. J. 2004, 377, 131-139. [CrossRef]

45. Begum, N.A.; Kobayashi, M.; Moriwaki, Y.; Matsumoto, M.; Toyoshima, K.; Seya, T. Mycobacterium bovis bcg cell wall and lipopolysaccharide induce a novel gene, bigm103, encoding a 7-tm protein: Identification of a new protein family having zn-transporter and zn-metalloprotease signatures. Genomics 2002, 80, 630-645. [CrossRef]

46. Ryu, M.S.; Lichten, L.A.; Liuzzi, J.P.; Cousins, R.J. Zinc transporters znt1 (slc30a1), zip8 (slc39a8) and zip10 (slc39a10) in mouse red blood cells are differentially regulated during erythroid development and by dietary zinc deficiency. J. Nutr. 2008, 138, 2076-2083. [CrossRef]

47. Matsuura, W.; Yamazaki, T.; Yamaguchi-Iwai, Y.; Masuda, S.; Nagao, M.; Andrews, G.K.; Kambe, T. Slc39a9 (zip9) regulates zinc homeostasis in the secretory pathway: Characterization of the zip subfamily i protein in vertebrate cells. Biosci. Biotechnol. Biochem. 2009, 73, 1142-1148. [CrossRef]

48. Thomas, P.; Pang, Y.; Dong, J.; Berg, A.H. Identification and characterization of membrane androgen receptors in the zip9 zinc transporter subfamily: Ii. Role of human zip9 in testosterone-induced prostate and breast cancer cell apoptosis. Endocrinology 2014, 155, 4250-4265. [CrossRef]

49. Kagara, N.; Tanaka, N.; Noguchi, S.; Hirano, T. Zinc and its transporter zip10 are involved in invasive behavior of breast cancer cells. Cancer Sci. 2007, 98, 692-697. [CrossRef]

50. Kaler, P.; Prasad, R. Molecular cloning and functional characterization of novel zinc transporter rzip10 (slc39a10) involved in zinc uptake across rat renal brush-border membrane. Am. J. Physiol. Renal Physiol. 2007, 292, F217-F229. [CrossRef]

51. Pawan, K.; Neeraj, S.; Sandeep, K.; Kanta Ratho, R.; Rajendra, P. Upregulation of slc39a10 gene expression in response to thyroid hormones in intestine and kidney. Biochim. Biophys. Acta 2007, 1769, 117-123. [CrossRef]

52. Kelleher, S.L.; Velasquez, V.; Croxford, T.P.; McCormick, N.H.; Lopez, V.; MacDavid, J. Mapping the zinc-transporting system in mammary cells: Molecular analysis reveals a phenotype-dependent zinc-transporting network during lactation. J. Cell. Physiol. 2012, 227, 1761-1770. [CrossRef]

53. Yu, Y.; Wu, A.; Zhang, Z.; Yan, G.; Zhang, F.; Zhang, L.; Shen, X.; Hu, R.; Zhang, Y.; Zhang, K.; et al. Characterization of the gufa subfamily member slc39a11/zip11 as a zinc transporter. J. Nutr. Biochem. 2013, 24, 1697-1708. [CrossRef]

54. Chowanadisai, W.; Graham, D.M.; Keen, C.L.; Rucker, R.B.; Messerli, M.A. Neurulation and neurite extension require the zinc transporter zip12 (slc39a12). Proc. Natl. Acad. Sci. USA 2013, 110, 9903-9908. [CrossRef]

55. Zhao, L.; Oliver, E.; Maratou, K.; Atanur, S.S.; Dubois, O.D.; Cotroneo, E.; Chen, C.N.; Wang, L.; Arce, C.; Chabosseau, P.L.; et al. The zinc transporter zip12 regulates the pulmonary vascular response to chronic hypoxia. Nature 2015, 524, 356-360. [CrossRef]

56. Bin, B.H.; Fukada, T.; Hosaka, T.; Yamasaki, S.; Ohashi, W.; Hojyo, S.; Miyai, T.; Nishida, K.; Yokoyama, S.; Hirano, T. Biochemical characterization of human zip13 protein: A homo-dimerized zinc transporter involved in the spondylocheiro dysplastic ehlers-danlos syndrome. J. Biol. Chem. 2011, 286, 40255-40265. [CrossRef]

57. Fukada, T.; Civic, N.; Furuichi, T.; Shimoda, S.; Mishima, K.; Higashiyama, H.; Idaira, Y.; Asada, Y.; Kitamura, H.; Yamasaki, S.; et al. The zinc transporter slc39a13/zip13 is required for connective tissue development; its involvement in bmp/tgf-beta signaling pathways. PloS ONE 2008, 3, e3642. [CrossRef]

58. Liuzzi, J.P.; Aydemir, F.; Nam, H.; Knutson, M.D.; Cousins, R.J. Zip14 (slc39a14) mediates non-transferrin-bound iron uptake into cells. Proc. Natl. Acad. Sci. USA 2006, 103, 13612-13617. [CrossRef]

59. Liuzzi, J.P.; Lichten, L.A.; Rivera, S.; Blanchard, R.K.; Aydemir, T.B.; Knutson, M.D.; Ganz, T.; Cousins, R.J. Interleukin-6 regulates the zinc transporter zip14 in liver and contributes to the hypozincemia of the acute-phase response. Proc. Natl. Acad. Sci. USA 2005, 102, 6843-6848. [CrossRef]

60. Tominaga, K.; Kagata, T.; Johmura, Y.; Hishida, T.; Nishizuka, M.; Imagawa, M. Slc39a14, a lzt protein, is induced in adipogenesis and transports zinc. FEBS J. 2005, 272, 1590-1599. [CrossRef]

61. Zhao, N.; Gao, J.; Enns, C.A.; Knutson, M.D. Zrt/irt-like protein 14 (zip14) promotes the cellular assimilation of iron from transferrin. J. Biol. Chem. 2010, 285, 32141-32150. [CrossRef] [PubMed] 
62. Aydemir, T.B.; Troche, C.; Kim, M.H.; Cousins, R.J. Hepatic zip14-mediated zinc transport contributes to endosomal insulin receptor trafficking and glucose metabolism. J. Biol. Chem. 2016, 291, 23939-23951. [CrossRef] [PubMed]

63. Palmiter, R.D.; Findley, S.D. Cloning and functional characterization of a mammalian zinc transporter that confers resistance to zinc. EMBO J. 1995, 14, 639-649. [CrossRef] [PubMed]

64. Palmiter, R.D.; Huang, L. Efflux and compartmentalization of zinc by members of the slc30 family of solute carriers. Pflugers Archiv.Eur. J. Physiol. 2004, 447, 744-751. [CrossRef] [PubMed]

65. Guo, L.; Lichten, L.A.; Ryu, M.S.; Liuzzi, J.P.; Wang, F.; Cousins, R.J. Stat5-glucocorticoid receptor interaction and mtf-1 regulate the expression of znt2 (slc30a2) in pancreatic acinar cells. Proc. Natl. Acad. Sci. USA 2010, 107, 2818-2823. [CrossRef] [PubMed]

66. Liuzzi, J.P.; Blanchard, R.K.; Cousins, R.J. Differential regulation of zinc transporter 1, 2 and 4 mrna expression by dietary zinc in rats. J. Nutr. 2001, 131, 46-52. [CrossRef]

67. Lopez, V.; Kelleher, S.L. Zinc transporter-2 (znt2) variants are localized to distinct subcellular compartments and functionally transport zinc. Biochem. J. 2009, 422, 43-52. [CrossRef]

68. Palmiter, R.D.; Cole, T.B.; Findley, S.D. Znt-2, a mammalian protein that confers resistance to zinc by facilitating vesicular sequestration. EMBO J. 1996, 15, 1784-1791. [CrossRef]

69. Palmiter, R.D.; Cole, T.B.; Quaife, C.J.; Findley, S.D. ZnT-3, a putative transporter of zinc into synaptic vesicles. Proc. Natl. Acad. Sci. USA 1996, 93, 14934-14939. [CrossRef]

70. Salazar, G.; Love, R.; Styers, M.L.; Werner, E.; Peden, A.; Rodriguez, S.; Gearing, M.; Wainer, B.H.; Faundez, V. AP-3-dependent mechanisms control the targeting of a chloride channel (ClC-3) in neuronal and non-neuronal cells. J. Biol. Chem. 2004, 279, 25430-25439. [CrossRef]

71. Smidt, K.; Jessen, N.; Petersen, A.B.; Larsen, A.; Magnusson, N.; Jeppesen, J.B.; Stoltenberg, M.; Culvenor, J.G.; Tsatsanis, A.; Brock, B.; et al. SLC30A3 responds to glucose- and zinc variations in beta-cells and is critical for insulin production and in vivo glucose-metabolism during beta-cell stress. PLoS ONE 2009, 4, e5684. [CrossRef] [PubMed]

72. Wenzel, H.J.; Cole, T.B.; Born, D.E.; Schwartzkroin, P.A.; Palmiter, R.D. Ultrastructural localization of zinc transporter-3 (ZnT-3) to synaptic vesicle membranes within mossy fiber boutons in the hippocampus of mouse and monkey. Proc. Natl. Acad. Sci. USA 1997, 94, 12676-12681. [CrossRef] [PubMed]

73. McCormick, N.H.; Kelleher, S.L. Znt4 provides zinc to zinc-dependent proteins in the trans-golgi network critical for cell function and zn export in mammary epithelial cells. Am. J. Physiol. Cell Physiol. 2012, 303, C291-C297. [CrossRef] [PubMed]

74. Michalczyk, A.A.; Allen, J.; Blomeley, R.C.; Ackland, M.L. Constitutive expression of hznt4 zinc transporter in human breast epithelial cells. Biochem. J. 2002, 364, 105-113. [CrossRef]

75. Murgia, C.; Vespignani, I.; Cerase, J.; Nobili, F.; Perozzi, G. Cloning, expression and vesicular localization of zinc transporter dri 27/znt4 in intestinal tissue and cells. Am. J. Physiol. 1999, 277, G1231-G1239. [CrossRef]

76. Inoue, K.; Matsuda, K.; Itoh, M.; Kawaguchi, H.; Tomoike, H.; Aoyagi, T.; Nagai, R.; Hori, M.; Nakamura, Y.; Tanaka, T. Osteopenia and male-specific sudden cardiac death in mice lacking a zinc transporter gene, znt5. Human Mol. Genet. 2002, 11, 1775-1784. [CrossRef]

77. Jackson, K.A.; Helston, R.M.; McKay, J.A.; O’Neill, E.D.; Mathers, J.C.; Ford, D. Splice variants of the human zinc transporter znt5 (slc30a5) are differentially localized and regulated by zinc through transcription and mrna stability. J. Biol. Chem. 2007, 282, 10423-10431. [CrossRef]

78. Kambe, T.; Narita, H.; Yamaguchi-Iwai, Y.; Hirose, J.; Amano, T.; Sugiura, N.; Sasaki, R.; Mori, K.; Iwanaga, T.; Nagao, M. Cloning and characterization of a novel mammalian zinc transporter, zinc transporter 5, abundantly expressed in pancreatic beta cells. J. Biol. Chem. 2002, 277, 19049-19055. [CrossRef]

79. Huang, L.; Kirschke, C.P.; Gitschier, J. Functional characterization of a novel mammalian zinc transporter, znt6. J. Biol. Chem. 2002, 277, 26389-26395. [CrossRef]

80. Smith, J.L.; Xiong, S.; Markesbery, W.R.; Lovell, M.A. Altered expression of zinc transporters-4 and -6 in mild cognitive impairment, early and late alzheimer's disease brain. Neuroscience 2006, 140, 879-888. [CrossRef]

81. Asano, N.; Kondoh, M.; Ebihara, C.; Fujii, M.; Nakanishi, T.; Soares, M.J.; Nakashima, E.; Tanaka, K.; Sato, M.; Watanabe, Y. Expression profiles of zinc transporters in rodent placental models. Toxicol. Lett. 2004, 154, 45-53. [CrossRef] [PubMed]

82. Kirschke, C.P.; Huang, L. Znt7, a novel mammalian zinc transporter, accumulates zinc in the golgi apparatus. J. Biol. Chem. 2003, 278, 4096-4102. [CrossRef] [PubMed] 
83. Suzuki, T.; Ishihara, K.; Migaki, H.; Matsuura, W.; Kohda, A.; Okumura, K.; Nagao, M.; Yamaguchi-Iwai, Y.; Kambe, T. Zinc transporters, znt5 and znt7, are required for the activation of alkaline phosphatases, zinc-requiring enzymes that are glycosylphosphatidylinositol-anchored to the cytoplasmic membrane. J. Biol. Chem. 2005, 280, 637-643. [CrossRef] [PubMed]

84. Chimienti, F.; Devergnas, S.; Favier, A.; Seve, M. Identification and cloning of a beta-cell-specific zinc transporter, znt-8, localized into insulin secretory granules. Diabetes 2004, 53, 2330-2337. [CrossRef] [PubMed]

85. Murgia, C.; Devirgiliis, C.; Mancini, E.; Donadel, G.; Zalewski, P.; Perozzi, G. Diabetes-linked zinc transporter znt8 is a homodimeric protein expressed by distinct rodent endocrine cell types in the pancreas and other glands. Nutr. Metab. Cardiovasc. Dis. 2009, 19, 431-439. [CrossRef] [PubMed]

86. Palmiter, R.D. Protection against zinc toxicity by metallothionein and zinc transporter 1. Proc. Natl. Acad. Sci. USA 2004, 101, 4918-4923. [CrossRef]

87. Kambe, T.; Tsuji, T.; Hashimoto, A.; Itsumura, N. The physiological, biochemical and molecular roles of zinc transporters in zinc homeostasis and metabolism. Physiol. Rev. 2015, 95, 749-784. [CrossRef]

88. Perez, Y.; Shorer, Z.; Liani-Leibson, K.; Chabosseau, P.; Kadir, R.; Volodarsky, M.; Halperin, D.; Barber-Zucker, S.; Shalev, H.; Schreiber, R.; et al. Slc30a9 mutation affecting intracellular zinc homeostasis causes a novel cerebro-renal syndrome. Brain J. Neurol. 2017, 140, 928-939. [CrossRef]

89. Bosomworth, H.J.; Thornton, J.K.; Coneyworth, L.J.; Ford, D.; Valentine, R.A. Efflux function, tissue-specific expression and intracellular trafficking of the zn transporter znt10 indicate roles in adult zn homeostasis. Met. Integr. Biometal Sci. 2012, 4, 771-779. [CrossRef]

90. Patrushev, N.; Seidel-Rogol, B.; Salazar, G. Angiotensin ii requires zinc and downregulation of the zinc transporters znt3 and znt10 to induce senescence of vascular smooth muscle cells. PLoS ONE 2012, 7, e33211. [CrossRef]

91. Seve, M.; Chimienti, F.; Devergnas, S.; Favier, A. In silico identification and expression of slc30 family genes: An expressed sequence tag data mining strategy for the characterization of zinc transporters' tissue expression. BMC Genom. 2004, 5, 32. [CrossRef] [PubMed]

92. Mawson, C.A.; Fischer, M.I. The occurrence of zinc in the human prostate gland. Can. J. Med. Sci. 1952, 30, 336-339. [CrossRef] [PubMed]

93. Gyorkey, F.; Min, K.W.; Huff, J.A.; Gyorkey, P. Zinc and magnesium in human prostate gland: Normal, hyperplastic and neoplastic. Cancer Res. 1967, 27, 1348-1353. [PubMed]

94. Zaichick, V.; Sviridova, T.V.; Zaichick, S.V. Zinc in the human prostate gland: Normal, hyperplastic and cancerous. Int. Urol. Nephrol. 1997, 29, 565-574. [CrossRef] [PubMed]

95. Costello, L.C.; Franklin, R.B. The clinical relevance of the metabolism of prostate cancer; zinc and tumor suppression: Connecting the dots. Mol. Cancer 2006, 5, 17. [CrossRef] [PubMed]

96. Christudoss, P.; Selvakumar, R.; Fleming, J.J.; Gopalakrishnan, G. Zinc status of patients with benign prostatic hyperplasia and prostate carcinoma. Indian J. Urol. 2011, 27, 14-18. [CrossRef]

97. Zhao, J.; Wu, Q.; Hu, X.; Dong, X.; Wang, L.; Liu, Q.; Long, Z.; Li, L. Comparative study of serum zinc concentrations in benign and malignant prostate disease: A systematic review and meta-analysis. Sci. Rep. 2016, 6, 25778. [CrossRef]

98. Baltaci, A.K.; Yuce, K. Zinc transporter proteins. Neurochem. Res. 2018, 43, 517-530. [CrossRef]

99. Hara, T.; Takeda, T.A.; Takagishi, T.; Fukue, K.; Kambe, T.; Fukada, T. Physiological roles of zinc transporters: Molecular and genetic importance in zinc homeostasis. J. Physiol. Sci. 2017, 67, 283-301. [CrossRef]

100. Kimura, T.; Kambe, T. The functions of metallothionein and zip and znt transporters: An overview and perspective. Int. J. Mol. Sci. 2016, 17, 336. [CrossRef]

101. Johnson, L.A.; Kanak, M.A.; Kajdacsy-Balla, A.; Pestaner, J.P.; Bagasra, O. Differential zinc accumulation and expression of human zinc transporter 1 (hzip1) in prostate glands. Methods 2010, 52, 316-321. [CrossRef] [PubMed]

102. Huang, L.; Kirschke, C.P.; Zhang, Y. Decreased intracellular zinc in human tumorigenic prostate epithelial cells: A possible role in prostate cancer progression. Cancer Cell Int. 2006, 6, 10. [CrossRef] [PubMed]

103. Costello, L.C.; Franklin, R.B.; Zou, J.; Feng, P.; Bok, R.; Swanson, M.G.; Kurhanewicz, J. Human prostate cancer zip1/zinc/citrate genetic/metabolic relationship in the tramp prostate cancer animal model. Cancer Biol. Ther. 2011, 12, 1078-1084. [CrossRef] [PubMed] 
104. Franklin, R.B.; Feng, P.; Milon, B.; Desouki, M.M.; Singh, K.K.; Kajdacsy-Balla, A.; Bagasra, O.; Costello, L.C. Hzip1 zinc uptake transporter down regulation and zinc depletion in prostate cancer. Mol. Cancer 2005, 4, 32. [CrossRef] [PubMed]

105. Gaither, L.A.; Eide, D.J. Eukaryotic zinc transporters and their regulation. Biometals 2001, 14, $251-270$. [CrossRef]

106. Desouki, M.M.; Geradts, J.; Milon, B.; Franklin, R.B.; Costello, L.C. Hzip2 and hzip3 zinc transporters are down regulated in human prostate adenocarcinomatous glands. Mol. Cancer 2007, 6, 37. [CrossRef]

107. Chen, Q.G.; Zhang, Z.; Yang, Q.; Shan, G.Y.; Yu, X.Y.; Kong, C.Z. The role of zinc transporter zip4 in prostate carcinoma. Urol. Oncol. 2012, 30, 906-911. [CrossRef]

108. Hasumi, M.; Suzuki, K.; Matsui, H.; Koike, H.; Ito, K.; Yamanaka, H. Regulation of metallothionein and zinc transporter expression in human prostate cancer cells and tissues. Cancer Lett. 2003, 200, 187-195. [CrossRef]

109. Henshall, S.M.; Afar, D.E.; Rasiah, K.K.; Horvath, L.G.; Gish, K.; Caras, I.; Ramakrishnan, V.; Wong, M.; Jeffry, U.; Kench, J.G.; et al. Expression of the zinc transporter znt4 is decreased in the progression from early prostate disease to invasive prostate cancer. Oncogene 2003, 22, 6005-6012. [CrossRef]

110. Singh, C.K.; Malas, K.M.; Tydrick, C.; Siddiqui, I.A.; Iczkowski, K.A.; Ahmad, N. Analysis of zinc-exporters expression in prostate cancer. Sci. Rep. 2016, 6, 36772. [CrossRef]

111. Tepaamorndech, S.; Huang, L.; Kirschke, C.P. A null-mutation in the znt7 gene accelerates prostate tumor formation in a transgenic adenocarcinoma mouse prostate model. Cancer Lett. 2011, 308, 33-42. [CrossRef] [PubMed]

112. Webber, M.M.; Waghray, A.; Bello, D. Prostate-specific antigen, a serine protease, facilitates human prostate cancer cell invasion. Clin. Cancer Res. 1995, 1, 1089-1094. [PubMed]

113. Ishii, K.; Otsuka, T.; Iguchi, K.; Usui, S.; Yamamoto, H.; Sugimura, Y.; Yoshikawa, K.; Hayward, S.W.; Hirano, K. Evidence that the prostate-specific antigen (psa)/zn2+ axis may play a role in human prostate cancer cell invasion. Cancer Lett. 2004, 207, 79-87. [CrossRef] [PubMed]

114. Uzzo, R.G.; Leavis, P.; Hatch, W.; Gabai, V.L.; Dulin, N.; Zvartau, N.; Kolenko, V.M. Zinc inhibits nuclear factor-kappa b activation and sensitizes prostate cancer cells to cytotoxic agents. Clin. Cancer Res. 2002, 8, 3579-3583.

115. Uzzo, R.G.; Crispen, P.L.; Golovine, K.; Makhov, P.; Horwitz, E.M.; Kolenko, V.M. Diverse effects of zinc on nf-kappab and ap-1 transcription factors: Implications for prostate cancer progression. Carcinogenesis 2006, 27, 1980-1990. [CrossRef]

116. Kim, Y.R.; Kim, I.J.; Kang, T.W.; Choi, C.; Kim, K.K.; Kim, M.S.; Nam, K.I.; Jung, C. Hoxb13 downregulates intracellular zinc and increases nf-kappab signaling to promote prostate cancer metastasis. Oncogene 2014, 33, 4558-4567. [CrossRef]

117. Ishii, K.; Usui, S.; Sugimura, Y.; Yamamoto, H.; Yoshikawa, K.; Hirano, K. Inhibition of aminopeptidase $n$ (ap-n) and urokinase-type plasminogen activator (upa) by zinc suppresses the invasion activity in human urological cancer cells. Biol. Pharm. Bull. 2001, 24, 226-230. [CrossRef]

118. Adzersen, K.H.; Jess, P.; Freivogel, K.W.; Gerhard, I.; Bastert, G. Raw and cooked vegetables, fruits, selected micronutrients and breast cancer risk: A case-control study in germany. Nutr. Cancer 2003, 46, 131-137. [CrossRef]

119. Schlag, P.; Seeling, W.; Merkle, P.; Betzler, M. [changes of serum-zinc in breast cancer (author's transl)]. Langenbecks Arch. Chir. 1978, 346, 129-133. [CrossRef]

120. Geraki, K.; Farquharson, M.J.; Bradley, D.A. Concentrations of fe, cu and zn in breast tissue: A synchrotron xrf study. Phys. Med. Biol. 2002, 47, 2327-2339. [CrossRef]

121. Margalioth, E.J.; Schenker, J.G.; Chevion, M. Copper and zinc levels in normal and malignant tissues. Cancer 1983, 52, 868-872. [CrossRef]

122. Santoliquido, P.M.; Southwick, H.W.; Olwin, J.H. Trace metal levels in cancer of the breast. Surg. Gynecol. Obstet. 1976, 142, 65-70. [PubMed]

123. Alam, S.; Kelleher, S.L. Cellular mechanisms of zinc dysregulation: A perspective on zinc homeostasis as an etiological factor in the development and progression of breast cancer. Nutrients 2012, 4, 875-903. [CrossRef] [PubMed]

124. Kasper, G.; Weiser, A.A.; Rump, A.; Sparbier, K.; Dahl, E.; Hartmann, A.; Wild, P.; Schwidetzky, U.; Castanos-Velez, E.; Lehmann, K. Expression levels of the putative zinc transporter liv-1 are associated with a better outcome of breast cancer patients. Int. J. Cancer 2005, 117, 961-973. [CrossRef] [PubMed] 
125. Matsui, C.; Takatani-Nakase, T.; Hatano, Y.; Kawahara, S.; Nakase, I.; Takahashi, K. Zinc and its transporter zip6 are key mediators of breast cancer cell survival under high glucose conditions. FEBS Lett. 2017, 591, 3348-3359. [CrossRef] [PubMed]

126. Takatani-Nakase, T. Zinc transporters and the progression of breast cancers. Biol. Pharm. Bull. 2018, 41, 1517-1522. [CrossRef]

127. Hogstrand, C.; Kille, P.; Ackland, M.L.; Hiscox, S.; Taylor, K.M. A mechanism for epithelial-mesenchymal transition and anoikis resistance in breast cancer triggered by zinc channel zip6 and stat 3 (signal transducer and activator of transcription 3). Biochem. J. 2013, 455, 229-237. [CrossRef]

128. Shen, H.; Qin, H.; Guo, J. Concordant correlation of liv-1 and e-cadherin expression in human breast cancer cell mcf-7. Mol. Biol. Rep. 2009, 36, 653-659. [CrossRef]

129. Gumulec, J.; Masarik, M.; Krizkova, S.; Adam, V.; Hubalek, J.; Hrabeta, J.; Eckschlager, T.; Stiborova, M.; Kizek, R. Insight to physiology and pathology of zinc(ii) ions and their actions in breast and prostate carcinoma. Curr. Med. Chem. 2011, 18, 5041-5051. [CrossRef]

130. Manning, D.L.; Robertson, J.F.; Ellis, I.O.; Elston, C.W.; McClelland, R.A.; Gee, J.M.; Jones, R.J.; Green, C.D.; Cannon, P.; Blamey, R.W.; et al. Oestrogen-regulated genes in breast cancer: Association of pliv1 with lymph node involvement. Eur. J. Cancer 1994, 30A, 675-678. [CrossRef]

131. Schneider, J.; Ruschhaupt, M.; Buness, A.; Asslaber, M.; Regitnig, P.; Zatloukal, K.; Schippinger, W.; Ploner, F.; Poustka, A.; Sultmann, H. Identification and meta-analysis of a small gene expression signature for the diagnosis of estrogen receptor status in invasive ductal breast cancer. Int. J. Cancer 2006, 119, 2974-2979. [CrossRef] [PubMed]

132. Johnston, S.R. New strategies in estrogen receptor-positive breast cancer. Clin. Cancer Res. 2010, 16, $1979-1987$. [CrossRef] [PubMed]

133. Jordan, V.C. Tamoxifen: A most unlikely pioneering medicine. Nat. Rev. Drug Discov. 2003, 2, $205-213$. [CrossRef] [PubMed]

134. Lopez, V.; Kelleher, S.L. Zip6-attenuation promotes epithelial-to-mesenchymal transition in ductal breast tumor (t47d) cells. Exp. Cell Res. 2010, 316, 366-375. [CrossRef]

135. Taylor, K.M.; Vichova, P.; Jordan, N.; Hiscox, S.; Hendley, R.; Nicholson, R.I. Zip7-mediated intracellular zinc transport contributes to aberrant growth factor signaling in antihormone-resistant breast cancer cells. Endocrinology 2008, 149, 4912-4920. [CrossRef] [PubMed]

136. Costello, L.C.; Levy, B.A.; Desouki, M.M.; Zou, J.; Bagasra, O.; Johnson, L.A.; Hanna, N.; Franklin, R.B. Decreased zinc and downregulation of zip3 zinc uptake transporter in the development of pancreatic adenocarcinoma. Cancer Biol. Ther. 2011, 12, 297-303. [CrossRef] [PubMed]

137. Li, M.; Zhang, Y.; Liu, Z.; Bharadwaj, U.; Wang, H.; Wang, X.; Zhang, S.; Liuzzi, J.P.; Chang, S.M.; Cousins, R.J.; et al. Aberrant expression of zinc transporter zip4 (slc39a4) significantly contributes to human pancreatic cancer pathogenesis and progression. Proc. Natl. Acad. Sci. USA 2007, 104, 18636-18641. [CrossRef]

138. Lipman, T.O.; Diamond, A.; Mellow, M.H.; Patterson, K.Y. Esophageal zinc content in human squamous esophageal cancer. J. Am. Coll. Nutr. 1987, 6, 41-46. [CrossRef]

139. Jin, J.; Li, Z.; Liu, J.; Wu, Y.; Gao, X.; He, Y. Knockdown of zinc transporter zip5 (slc39a5) expression significantly inhibits human esophageal cancer progression. Oncol. Rep. 2015, 34, 1431-1439. [CrossRef]

140. Huang, C.; Cui, X.; Sun, X.; Yang, J.; Li, M. Zinc transporters are differentially expressed in human non-small cell lung cancer. Oncotarget 2016, 7, 66935-66943. [CrossRef]

141. Jing, H.W.; Kong, C.Z.; Liu, T.; Zeng, Y.; Zhang, Z. Zinc transporter 1 (znt1) is overexpressed in bladder cancer and promotes the proliferation and invasion of bladder cancer biu87 cells. Int. J. Clin. Exp. Med. 2018, 11, 5323-5331.

142. Tashiro, H.; Kawamoto, T.; Okubo, T.; Koide, O. Variation in the distribution of trace elements in hepatoma. Biol. Trace Elem. Res. 2003, 95, 49-63. [CrossRef]

143. Franz, M.C.; Anderle, P.; Burzle, M.; Suzuki, Y.; Freeman, M.R.; Hediger, M.A.; Kovacs, G. Zinc transporters in prostate cancer. Mol. Aspects Med. 2013, 34, 735-741. [CrossRef] [PubMed]

144. Costello, L.C.; Fenselau, C.C.; Franklin, R.B. Evidence for operation of the direct zinc ligand exchange mechanism for trafficking, transport and reactivity of zinc in mammalian cells. J. Inorg. Biochem. 2011, 105, 589-599. [CrossRef]

145. Costello, L.C.; Zou, J.; Franklin, R.B. In situ clinical evidence that zinc levels are decreased in breast invasive ductal carcinoma. Cancer Causes Control. 2016, 27, 729-735. [CrossRef] 
146. Costello, L.C.; Franklin, R.B. A comprehensive review of the role of zinc in normal prostate function and metabolism; and its implications in prostate cancer. Arch. Biochem. Biophys. 2016, 611, 100-112. [CrossRef]

147. Beyersmann, D.; Haase, H. Functions of zinc in signaling, proliferation and differentiation of mammalian cells. Biometals 2001, 14, 331-341. [CrossRef]

148. Costello, L.C.; Franklin, R.B.; Feng, P.; Tan, M.; Bagasra, O. Zinc and prostate cancer: A critical scientific, medical and public interest issue (united states). Cancer Causes Control. 2005, 16, 901-915. [CrossRef]

149. Thiers, R.E.; Vallee, B.L. Distribution of metals in subcellular fractions of rat liver. J. Biol. Chem. 1957, 226, 911-920.

150. Smeyers-Verbeke, J.; May, C.; Drochmans, P.; Massart, D.L. The determination of cu, zn and mn in subcellular rat liver fractions. Anal. Biochem. 1977, 83, 746-753. [CrossRef]

151. Franklin, R.B.; Milon, B.; Feng, P.; Costello, L.C. Zinc and zinc transporters in normal prostate and the pathogenesis of prostate cancer. Front. Biosci 2005, 10, 2230-2239. [CrossRef]

152. Marshall, K.M.; Laval, M.; Estacio, O.; Hudson, D.F.; Kalitsis, P.; Shulkes, A.; Baldwin, G.S.; Patel, O. Activation by zinc of the human gastrin gene promoter in colon cancer cells in vitro and in vivo. Metallomics 2015, 7, 1390-1398. [CrossRef] [PubMed]

153. Liang, J.Y.; Liu, Y.Y.; Zou, J.; Franklin, R.B.; Costello, L.C.; Feng, P. Inhibitory effect of zinc on human prostatic carcinoma cell growth. Prostate 1999, 40, 200-207. [CrossRef]

154. Feng, P.; Li, T.L.; Guan, Z.X.; Franklin, R.B.; Costello, L.C. Direct effect of zinc on mitochondrial apoptogenesis in prostate cells. Prostate 2002, 52, 311-318. [CrossRef]

155. Feng, P.; Liang, J.Y.; Li, T.L.; Guan, Z.X.; Zou, J.; Franklin, R.; Costello, L.C. Zinc induces mitochondria apoptogenesis in prostate cells. Mol. Urol. 2000, 4, 31-36. [PubMed]

156. Kriedt, C.L.; Baldassare, J.; Shah, M.; Klein, C. Zinc functions as a cytotoxic agent for prostate cancer cells independent of culture and growth conditions. J. Exp. Ther. Oncol. 2010, 8, 287-295. [PubMed]

157. Shah, M.R.; Kriedt, C.L.; Lents, N.H.; Hoyer, M.K.; Jamaluddin, N.; Klein, C.; Baldassare, J. Direct intra-tumoral injection of zinc-acetate halts tumor growth in a xenograft model of prostate cancer. J. Exp. Clin. Cancer Res. 2009, 28, 84. [CrossRef]

158. Nardinocchi, L.; Pantisano, V.; Puca, R.; Porru, M.; Aiello, A.; Grasselli, A.; Leonetti, C.; Safran, M.; Rechavi, G.; Givol, D.; et al. Zinc downregulates hif-1alpha and inhibits its activity in tumor cells in vitro and in vivo. PLoS ONE 2010, 5, e15048. [CrossRef]

159. Ishii, K.; Usui, S.; Sugimura, Y.; Yoshida, S.; Hioki, T.; Tatematsu, M.; Yamamoto, H.; Hirano, K. Aminopeptidase $\mathrm{n}$ regulated by zinc in human prostate participates in tumor cell invasion. Int. J. Cancer 2001, 92, 49-54. [CrossRef]

160. Golovine, K.; Makhov, P.; Uzzo, R.G.; Shaw, T.; Kunkle, D.; Kolenko, V.M. Overexpression of the zinc uptake transporter hzip1 inhibits nuclear factor-kappab and reduces the malignant potential of prostate cancer cells in vitro and in vivo. Clin. Cancer Res. 2008, 14, 5376-5384. [CrossRef]

161. Wetherell, D.; Baldwin, G.S.; Shulkes, A.; Bolton, D.; Ischia, J.; Patel, O. Zinc ion dyshomeostasis increases resistance of prostate cancer cells to oxidative stress via upregulation of hif1alpha. Oncotarget 2018, 9, 8463-8477. [CrossRef] [PubMed]

162. Feng, P.; Li, T.L.; Guan, Z.X.; Franklin, R.B.; Costello, L.C. Effect of zinc on prostatic tumorigenicity in nude mice. Ann. N Y Acad. Sci. 2003, 1010, 316-320. [CrossRef] [PubMed]

163. Prasad, A.S.; Mukhtar, H.; Beck, F.W.; Adhami, V.M.; Siddiqui, I.A.; Din, M.; Hafeez, B.B.; Kucuk, O. Dietary zinc and prostate cancer in the tramp mouse model. J. Med. Food 2010, 13, 70-76. [CrossRef] [PubMed]

164. To, P.K.; Do, M.H.; Cho, Y.S.; Kwon, S.Y.; Kim, M.S.; Jung, C. Zinc inhibits expression of androgen receptor to suppress growth of prostate cancer cells. Int. J. Mol. Sci. 2018, 19, 3062. [CrossRef]

165. Banudevi, S.; Elumalai, P.; Sharmila, G.; Arunkumar, R.; Senthilkumar, K.; Arunakaran, J. Protective effect of zinc on n-methyl-n-nitrosourea and testosterone-induced prostatic intraepithelial neoplasia in the dorsolateral prostate of sprague dawley rats. Exp. Biol. Med. 2011, 236, 1012-1021. [CrossRef]

166. Kristal, A.R.; Stanford, J.L.; Cohen, J.H.; Wicklund, K.; Patterson, R.E. Vitamin and mineral supplement use is associated with reduced risk of prostate cancer. Cancer Epidemiol Biomark. Prev. 1999, 8, 887-892.

167. Epstein, M.M.; Kasperzyk, J.L.; Andren, O.; Giovannucci, E.L.; Wolk, A.; Hakansson, N.; Andersson, S.O.; Johansson, J.E.; Fall, K.; Mucci, L.A. Dietary zinc and prostate cancer survival in a swedish cohort. Am. J. Clin. Nutr. 2011, 93, 586-593. [CrossRef] 
168. Costello, L.C.; Franklin, R.B. Aconitase activity, citrate oxidation and zinc inhibition in rat ventral prostate. Enzyme 1981, 26, 281-287. [CrossRef]

169. Gallus, S.; Foschi, R.; Negri, E.; Talamini, R.; Franceschi, S.; Montella, M.; Ramazzotti, V.; Tavani, A.; Dal Maso, L.; La Vecchia, C. Dietary zinc and prostate cancer risk: A case-control study from italy. Eur. Urol. 2007, 52, 1052-1056. [CrossRef]

170. Lagiou, P.; Wuu, J.; Trichopoulou, A.; Hsieh, C.C.; Adami, H.O.; Trichopoulos, D. Diet and benign prostatic hyperplasia: A study in greece. Urology 1999, 54, 284-290. [CrossRef]

171. Gonzalez, A.; Peters, U.; Lampe, J.W.; White, E. Zinc intake from supplements and diet and prostate cancer. Nutr. Cancer 2009, 61, 206-215. [CrossRef] [PubMed]

172. Leitzmann, M.F.; Stampfer, M.J.; Wu, K.; Colditz, G.A.; Willett, W.C.; Giovannucci, E.L. Zinc supplement use and risk of prostate cancer. J. Natl. Cancer Inst. 2003, 95, 1004-1007. [CrossRef] [PubMed]

(C) 2020 by the authors. Licensee MDPI, Basel, Switzerland. This article is an open access article distributed under the terms and conditions of the Creative Commons Attribution (CC BY) license (http://creativecommons.org/licenses/by/4.0/). 